\title{
Evaluation of a New Cerium Oxide-Bismuth Oxide-Based Nanobiocomposite as a Biocatalyst for Biodiesel Production
}

\author{
Anam Shahzadi ${ }^{1}$, Muhammad Waseem Mumtaz ${ }^{1}$, Hamid Mukhtar $^{2}{ }^{\circledR}$, Sadia Akram ${ }^{1}$, Tooba Touqeer ${ }^{1}$, \\ Vasudeo Zambare ${ }^{3,4}$ and Lew Christopher ${ }^{5,6, *(D)}$ \\ 1 Department of Chemistry, University of Gujrat, Gujrat 50700, Pakistan; 19121707-016@uog.edu.pk (A.S.); \\ muhammad.waseem@uog.edu.pk (M.W.M.); dr.sadia@uog.edu.pk (S.A.); tuba.toqir@gmail.com (T.T.) \\ 2 Institute of Industrial Biotechnology, Government College University, Lahore 54000, Pakistan; \\ hamidwaseer@yahoo.com \\ 3 Research and Development Department, Om Biotechnologies, Nashik 422011, India; \\ vasuzambare@gmail.com \\ 4 Aesthetika Eco Research Pvt. Ltd., Nashik 422010, India \\ 5 Biorefinery World, LLC, Rapid City, SD 57702, USA \\ 6 Lee Enterprises Consulting, Inc., Sherwood, AK 72120, USA \\ * Correspondence: 1christo@bio-ref.com
}

\section{check for} updates

Citation: Shahzadi, A.; Mumtaz, M.W.; Mukhtar, H.; Akram, S.; Touqeer, T.; Zambare, V.; Christopher, L. Evaluation of a New Cerium Oxide-Bismuth Oxide-Based Nanobiocomposite as a Biocatalyst for Biodiesel Production. Processes 2021, 9, 2012. https://doi.org/ $10.3390 /$ pr9112012

Academic Editors:

Chiing-Chang Chen and Farooq Sher

Received: 24 August 2021

Accepted: 3 November 2021

Published: 11 November 2021

Publisher's Note: MDPI stays neutral with regard to jurisdictional claims in published maps and institutional affiliations.

Copyright: (c) 2021 by the authors. Licensee MDPI, Basel, Switzerland. This article is an open access article distributed under the terms and conditions of the Creative Commons Attribution (CC BY) license (https:// creativecommons.org/licenses/by/ $4.0 /)$.

\begin{abstract}
Biodiesel is a promising renewable energy source that can be used together with other biofuels to help meet the growing energy needs of the rapidly increasing global population in an environmentally friendly way. In search for new and more efficient biodiesel production methods, this work reports on the synthesis and use of a novel biocatalyst that can function in a broader range of $\mathrm{pH}$ and temperature conditions, while producing high biodiesel yields from vegetable oils. Biodiesel was synthesized by transesterification of non-edible Eruca sativa oil using a lipase from Aspergillus niger that was immobilized on cerium oxide bismuth oxide nanoparticles. The synthesized nanoparticles were first grafted with polydopamine which facilitated the subsequent anchoring of the enzyme on the nanoparticle support. The enzyme activity, $\mathrm{pH}$ and temperature stability, and reusability of the immobilized lipase were superior to those of the free enzyme. Following response surface methodology optimization, the highest biodiesel yield of $90.6 \%$ was attained using $5 \mathrm{wt} \%$ biocatalyst, methanol to oil ratio of $6: 1$, reaction temperature of $40{ }^{\circ} \mathrm{C}, \mathrm{pH}$ of 7 , and reaction time of $60 \mathrm{~h}$. The produced biodiesel was characterized by Fourier transform infrared spectroscopy and its fatty acid methyl ester composition was determined by gas chromatography-mass spectrometry. Erucic acid methyl ester was identified as the major component in biodiesel, with $47.7 \mathrm{wt} \%$ of the total fatty acid methyl esters content. The novel nanobiocatalyst $\left(\mathrm{Bi}_{2} \mathrm{O}_{3} \cdot \mathrm{CeO}_{2} @ \mathrm{PDA} @\right.$ A.niger.Lipase $)$ has the potential to produce high biodiesel yields from a variety of vegetable oils.
\end{abstract}

Keywords: biodiesel; lipase; immobilization; cerium doped bismuth oxide nanoparticles; response surface methodology; fatty acid methyl esters

\section{Introduction}

Due to the immense increase in the world's population, growing concerns of fossil fuels depletion, fluctuating oil prices, and increased levels of greenhouse gas (GHG) emissions, alternative sources for renewable and sustainable energy production are needed. Efforts to produce, scale up and commercialize are focused on biofuels, such as cellulosic ethanol, biohydrogen, renewable hydrocarbon diesel, and biodiesel. Among these, biodiesel is considered as one of the most promising energy sources that is currently reaching the scale up and commercialization stage [1].

Biodiesel can be produced using two catalytic routes, i.e., chemical, and enzymatic. The chemical method is further classified into acid-catalyzed and base-catalyzed transesterification. In the base-catalyzed transesterification, $\mathrm{NaOH}$ and $\mathrm{KOH}$ are the most popular 
catalysts while for acid-catalyzed transesterification, $\mathrm{BF}_{3}$ and $\mathrm{H}_{2} \mathrm{SO}_{4}$ are frequently used. Esterification in presence of acids is generally slower than the base-catalyzed reaction. However, the chemical esterification of oils with high content of free fatty acids (FFA), such as waste and non-edible oils, including Eruca sativa oil, is problematic because it can cause saponification, decrease the biodiesel yield, and generate high amounts of wastewater [2]. These are drawbacks of the chemical route that is generally characterized as an energy-intensive and environmentally unfriendly process due to the required wastewater treatment, catalyst, and product recovery processing steps.

In contrast, the enzyme-catalyzed trans/esterification is becoming the preferred biodiesel production method due to the following advantages over the chemical method: ambient process conditions, lower treatment costs, reusable and renewable catalyst, superior substrate specificity, one-step conversion of triglycerides and FFA to biodiesel, lower alcohol to oil ratio, prevention of side reactions, less impurities, easier biodiesel separation, and fewer environmental concerns [3].

A number of lipase enzymes, both free and immobilized, are used in the biodiesel production process. The reproducibility and resistivity towards reaction conditions of the immobilized enzymes is generally higher than the non-immobilized enzymatic system. Enzymes are immobilized on various nanosupports for enhanced catalytic properties. Immobilization of enzymes on nanosupports has been reported to improve the effectiveness of transesterification, which benefits the production economics without affecting the yield or quality of biodiesel. The lipase immobilization is an environmentally friendly and economically advantageous process that is associated with lower energy consumption, broader feedstock specificity, and reduced post-treatment handling cost. The methods for enzyme immobilization include adsorption, physical entrapment, bio-conjugation and covalent immobilization [3].

Recently, it has been recognized that nanomaterials like carbon nanotubes, activated carbon, metal oxides, and silica-based nanoparticles hold promise for lipase immobilization and use. Enzymes immobilized on nanomaterials, such as nanocomposites (NC), are able to simultaneously catalyze multiple substrates which can bring about additional economic benefits [4]. Typically, nanoparticles, such as titanium oxide, calcium oxide, aluminumdoped iron oxide, cerium-doped silver oxide, copper oxide, zirconium oxide, iron oxide supported on gold, and magnesium oxide have been used as enzyme support [5].

The use of a spacer or linker can improve enzyme immobilization. Polydopamine (PDA) has been frequently applied for this purpose [6]. The polymerization of dopamine occurs on surfaces with high oxidative potential, such as cerium and bismuth oxides [7]. For example, PDA-coated cerium oxide has been reported to have good potential for lipase immobilization [8]. In this study, we aimed to develop a novel, low-cost, heterogeneous nanobiocomposite (NBC), which can serve as a solid biocatalyst in the synthesis of highyield biodiesel. The NBC was prepared by coating synthesized cerium oxide-bismuth oxide (COBO) nanoparticles with PDA and subsequent immobilization of a lipase from Aspergillus niger onto the solid support. Using the newly fabricated biocatalyst, the transesterification of E. sativa seed oil to biodiesel was optimized by response surface methodology (RSM.)

\section{Materials and Methods}

\subsection{Chemicals and Reagents}

Analytical grade chemicals i.e., dopamine hydrochloride, tris- $\mathrm{HCl}$ base, phosphate buffer, methanol, oxalic acid, ethanol, bismuth nitrate, cerium nitrate, Calcium chloride, acetone and phenolphthalein, etc., were purchased from Sigma-Aldrich (St. Louis, MO, USA). Lipase was produced from a locally isolated $A$. niger strain that was deposited in the culture bank of the Institute of Industrial Biotechnology, Government College University, Lahore, Pakistan. The enzyme was partially purified using ammonium sulfate precipitation and was lyophilized. Seed oil from E. sativa was purchased from a local shop in Gujrat, Pakistan. 


\subsection{Preparation of $C O B O$ Nanoparticles}

Different ratios of $\mathrm{COBO}$ nanoparticles were prepared by the co-precipitation method as described below. Oxalic acid ( $30 \mathrm{~g})$ was dissolved in $100 \mathrm{~mL}$ ethanol under continuous stirring for each $\mathrm{COBO}$ synthesis. For $\mathrm{NC1}, 100 \mathrm{~mL}$ of ethanol solution containing $4.8 \mathrm{~g}$ of bismuth nitrate was prepared. For NC2, $3.8 \mathrm{~g}$ of bismuth nitrate and $0.868 \mathrm{~g}$ of cerium nitrate were dissolved in $10 \mathrm{~mL}$ ethanol, and the volume was made up to $100 \mathrm{~mL}$ with additional ethanol. The same procedure was followed to prepare $100 \mathrm{~mL}$ ethanol solution of $1.9 \mathrm{~g}$ of bismuth nitrate and $3.4 \mathrm{~g}$ of cerium nitrate (NC3). The ethanol solutions for $\mathrm{NC} 1, \mathrm{NC} 2$ and NC3 were transferred into three separate necked flasks, respectively. The prepared oxalic acid solutions were slowly added to the three flasks along with continuous stirring. Following precipitation, the solutions were filtered, and the residue was ovendried at $60{ }^{\circ} \mathrm{C}$ for $1 \mathrm{~h}$. The dried product was then placed in a muffle furnace at $450{ }^{\circ} \mathrm{C}$ for $24 \mathrm{~h}$ in order to remove impurities.

\subsection{Grafting of $P D A$ on $C O B O$ Nanoparticles}

Grafting-aided PDA coating of nanoparticles was applied to form a nanocomposite. The COBO nanoparticles $(0.1 \mathrm{~g})$ were separately suspended in $20 \mathrm{~mL}$ of distilled water in three different flasks, and then $20 \mathrm{mmol}$ tris- $\mathrm{HCl}$ buffer $(\mathrm{pH} 8.5,20 \mathrm{~mL})$ was added in all suspensions. Thereafter, dopamine hydrochloride $(0.1 \mathrm{~g})$ was slowly introduced to the suspensions by continuous stirring for $1 \mathrm{~h}$. Under alkaline conditions, dopamine polymerized to PDA and formed a coating on the surface of the nanoparticles [5].

\subsection{Immobilization of Lipase on $\mathrm{COBO}$ NCs}

Phosphate buffer solution $(40 \mathrm{~mL})$ was mixed with $0.4 \mathrm{~g}$ of lipase in a $250 \mathrm{~mL}$ flask for each COBO. Next, $40 \mathrm{~mL}$ of PDA-coated cerium oxide bismuth oxide nanoparticles suspension was gradually poured into the lipase mixture and stirred at $4{ }^{\circ} \mathrm{C}$ for $3 \mathrm{~h}$. The formed nanobiocatalyst was washed with phosphate buffer to eliminate unreacted enzyme and then desiccated at $4{ }^{\circ} \mathrm{C}$. All three NBCs were prepared by the same method (Figure 1) [9].

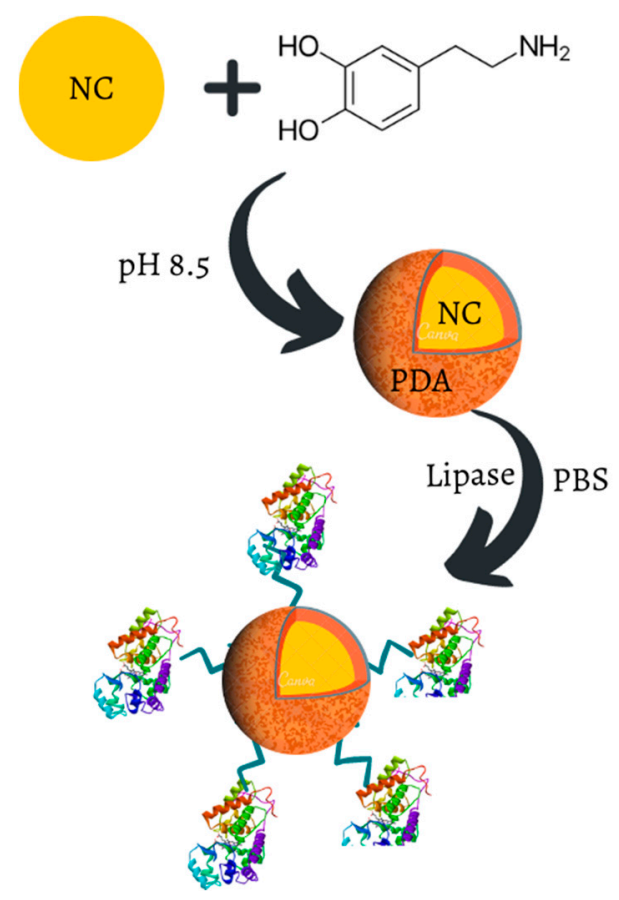

Figure 1. Schematic presentation of enzyme immobilization on PDA-coated nanoparticles.

\subsection{Characterization of Nanoparticles}

The nanoparticle characterization was performed by scanning electron microscopy (SEM), X-ray diffraction (XRD), and Fourier Transform Infrared (FTIR) spectroscopy. X'pert 
pro (PAnalytical) with $\mathrm{Cu} \mathrm{k} \alpha$ radiations of $\lambda=1.54 \mathrm{~A}^{\circ}$ and 20-80 $\theta$ scan-range and scan step size of 0.02 was used to obtain the XRD pattern of $\mathrm{COBO}$ nanoparticles and provide information about the dimensions of the COBO nanoparticles, their crystal phase and particle size. SEM microscope (S2380N, Hitachi, Ibaraki-ken, Japan) with $30 \mathrm{kV}$ energy, maximum magnification of 300,000 X and resolving power of $2.3 \mathrm{~nm}$ was used for estimation of the particle size and surface morphology of the $\mathrm{COBO}$ nanoparticles [10]. The formation of $\mathrm{COBO}$ nanoparticles and COBO-based nanocomposite $\left(\mathrm{CeO}_{2} \cdot \mathrm{Bi}_{2} \mathrm{O}_{3} @ \mathrm{PDA}\right)$ was confirmed using Cary 630 Agilent FTIR spectroscopy.

\subsection{Lipase Activity Assay}

A standard titrimetric method was applied to assay the enzyme activity of free and immobilized lipase from A. niger [11]. The assay mixture, comprised of $1.00 \mathrm{~m}$ of free lipase or $0.1 \mathrm{~g}$ of COBO immobilized lipase and $10 \%(v / v)$ olive oil $(10 \mathrm{~mL})$, was first homogenized in gum acacia $(10 \mathrm{~g})$ at $\mathrm{pH} 7$ using phosphate buffer $(5 \mathrm{~mL})$ and $0.6 \%(w / v)$ $\mathrm{CaCl}_{2}(2 \mathrm{~mL})$, and then incubated in a water-bath-shaker at $37^{\circ} \mathrm{C}$ for $1 \mathrm{~h}$. Thereafter, the reaction was arrested by adding $20 \mathrm{~mL}$ of acetone: ethanol (1:1). Then, a few drops of phenolphthalein were added and the fatty acids, released from oil during the lipase reaction, were titrated against a standard $0.1 \mathrm{~N} \mathrm{NaOH}$ solution. One unit of lipase activity (U) was defined as the amount of enzyme which released one micromole $(\mu \mathrm{mol})$ of fatty acids per minute under the specified assay conditions. The lipase activity was measured as follows:

$$
\text { Activity }(\mathrm{U} / \mathrm{mg})=\frac{\Delta \mathrm{V} \times \mathrm{N} \times 1000}{\mathrm{~m}(\text { sample }) \times 60}
$$

where, $\Delta \mathrm{V}=$ volume of $\mathrm{NaOH}$ in control flask - volume of $\mathrm{NaOH}$ in experimental flask during titration $(\mathrm{mL}) ; \mathrm{N}$ is the normality of $\mathrm{NaOH}(\mathrm{N}) ; \mathrm{m}$ (sample) is the mass of lipase $(\mathrm{mg}) ; 60$ is the incubation time ( $\mathrm{min})$.

\subsection{Effect of Temperature and $\mathrm{pH}$ on Lipase Activity}

The $\mathrm{pH}$ and temperature effect on the free and $\mathrm{COBO}$ immobilized lipase was investigated by employing the lipase activity assay protocol described in 2.6. The $\mathrm{pH}$ effect on lipase activity was studied at $37^{\circ} \mathrm{C}$ using phosphate buffers (pH 5, 6, 7, 8, 9, and 10). The effect of temperature at $25,30,35,40,45$, and $50{ }^{\circ} \mathrm{C}$ was determined at the lipase optimum $\mathrm{pH}$.

\subsection{Recycling of NBCs}

For the reusability studies, the transesterification of Eruca sativa seed oil was carried out using the synthesized NBCs at their optimum temperature for $24 \mathrm{~h}$. After completion of reaction, the NBCs were recovered by centrifugation, and their activities were determined using the lipase assay protocol described above.

\subsection{RSM Optimization of Biodiesel Production}

The optimization of biodiesel production process by means of NBC3 was done by a three-level central composite RSM was applied using design expert 10.07 software. The three independent parameters used in the biodiesel optimization studies were: A (reaction time in the range of $12-60 \mathrm{~h}$ ), B (NBC concentration in the range of $1-5 \%(w / v)$ ), $\mathrm{C}$ (methanol: oil ratio in the range from 3:1 to 9:1). Thirty reactions were carried out in accordance with the central composite design (CCD). A conical flask containing the specified amount of feedstock oil, methanol, biocatalyst, and $0.6 \%$ distilled water, were placed in a shaking incubator. The reaction was performed under conditions specified according to the RSM design at $600 \mathrm{rpm}$ and optimum temperature as determined in the temperature studies. When the reaction was completed, the glycerol co-product was separated from the biodiesel by pouring the mixture in a separatory funnel and letting it stand until two clearly distinguished layered were formed. The biodiesel product was then washed with warm water and distilled in a rotatory evaporator (Steroglass, Perugia, 
Italy) under vacuum to separate from the unreacted methanol. The purified biodiesel was quantified as grams of biodiesel produced per gram of feedstock transesterified.

\subsection{Recovery of $N B C S$}

Following oil transesterification to biodiesel, the $\mathrm{CeO}_{2} \cdot \mathrm{Bi}_{2} \mathrm{O}_{3} @ P D A @ A$.niger.Lipase nanobiocatalyst was separated from the glycerol and biodiesel by centrifugation (Sigma, Osterode, Germany) at $8000 \mathrm{rpm}$ for $5 \mathrm{~min}$. The recovered nanobiocatalyst was then water-washed, air-dried, and re-used.

\subsection{Characterization of Biodiesel}

FTIR with Cary 630 Agilent spectrometer and Gas Chromatography-Mass Spectrometry (GC-MS) using Shimadzu GCMS QP2010 with dB5-column possessing a diameter of $0.15 \mathrm{~mm}$ were used for biodiesel characterization. The GC-MS with a sample size of $1 \mu \mathrm{L}$, a 1:100 split ratio, and $1.2 \mathrm{~mL} / \mathrm{min}$ flow rate of helium carrier gas was used to determine the FAME content in biodiesel. The oven temperature was fixed in range of 150 to $250{ }^{\circ} \mathrm{C}$ on a rate of $4{ }^{\circ} \mathrm{C} / \mathrm{min}$. The MS scan range of the system was 30-550 m/z. NIST MS library of GC-MS was utilized to detect the methyl esters.

\section{Results}

3.1. Characterization of NCs

\subsubsection{FTIR Spectroscopy}

The FTIR spectroscopy of the synthesized nanocomposites was performed to estimate the purity and confirm the formation of required nanocomposites. The FTIR spectra of the synthesized nanocomposites are presented in Figure 2. The FTIR spectrum of bismuth oxide (NC1) (Figure 2a) has only one peak which corresponds to a O-Bi-O bond. The FTIR spectrum of $\mathrm{Ce}_{0.2} \mathrm{Bi}_{0.8}$ nanocomposite oxide (NC2) (Figure $2 \mathrm{~b}$ ) and $\mathrm{Ce}_{0.5} \mathrm{Bi}_{0.5}$ nanocomposite oxide (NC3) (Figure 2c) were almost identical, with a few variations. The peaks corresponding to O-Ce-O in the FTIR spectrum of NC3 (Figure 1c) were more intense than NC2 (Figure 1b). The stretching vibrations of the asymmetric O-Ce-O bond overlapped with that of the O-Bi-O bond at $655.8797 \mathrm{~cm}^{-1}$. The peak that appeared at $1390.50 \mathrm{~cm}^{-1}$ in both NC2 and NC3 (absent in the NC1) might be due to the N-O stretching band of nitrates or the vibrations of the carbonate-like species formed through adsorption of carbon dioxide by the cerium oxide nanoparticles. Furthermore, the peak for the O-H bond vibration, clearly visible in NC3 (Figure 2c), might be due to unreacted sodium hydroxide or moisture absorbed by the NCs $[12,13]$.

\subsubsection{SEM}

The surface of the synthesized nanomoieties was analyzed using SEM (Figure 2). The SEM image of $\mathrm{Bi}_{2} \mathrm{O}_{3}$ (Figure 3a) shows spherically shaped nanoparticles. This is consistent with the other literature reports [14]. In contrast, the SEM image of the $\mathrm{Ce}_{0.2} \mathrm{Bi}_{0.8}$ nanocomposite oxide (Figure $3 \mathrm{~b}$ ) and $\mathrm{Ce}_{0.5} \mathrm{Bi}_{0.5}$ nanocomposite oxide (Figure $3 c$ ) display an irregular shape. The small size of the nanoparticles observed by the SEM images suggests good Brownian movement.

\subsubsection{XRD}

XRD patterns of pure $\mathrm{Bi}_{2} \mathrm{O}_{3}$ and $\mathrm{COBO}$ nanocomposites are presented in Figure 4. The XRD pattern of pure $\mathrm{Bi}_{2} \mathrm{O}_{3}$ (Figure 4a) is in concurrence with the standard value of $\mathrm{Bi}_{2} \mathrm{O}_{3}$ (JCPDS No. 27-0052). The peaks obtained in the XRD plot of bismuth oxide correspond to the miller indices (121), (202), and (223). The XRD plot for the $\mathrm{Ce}_{0.2} \mathrm{Bi}_{0.8}$ nanocomposite oxide (NC2) is shown in Figure 4b. The appearance of peaks at 28.5, 32.75, 45.3, 55.9560 .55 and 68.5 correspond to miller indices (111), (200), (220), (311), (222), and (400) for $\mathrm{CeO}_{2}$ (JCPDS card no.43-1002). The XRD pattern for $\mathrm{Bi}_{0.5} \mathrm{Ce}_{0.5}$ nanocomposite oxide (NC3) as presented in Figure 4c reveals that the XRD peaks for both NC3 and NC2 coincide and appear at almost similar positions; however, the peaks corresponding to $\mathrm{CeO}_{2}$ exhibited 
higher intensity. The higher intensity of the peak corresponding to cerium oxide might be due to the high crystallinity or high content of the cerium oxide. The increase in the peak intensity with increased cerium concentration has already been reported by other researchers $[7,15]$. Moreover, the broadening of the peaks by increasing the cerium amount suggests reduction in the size of the nanocomposites. The size reduction might be helpful in gaining a better Brownian movement and ultimately, a better enzyme activity [12].

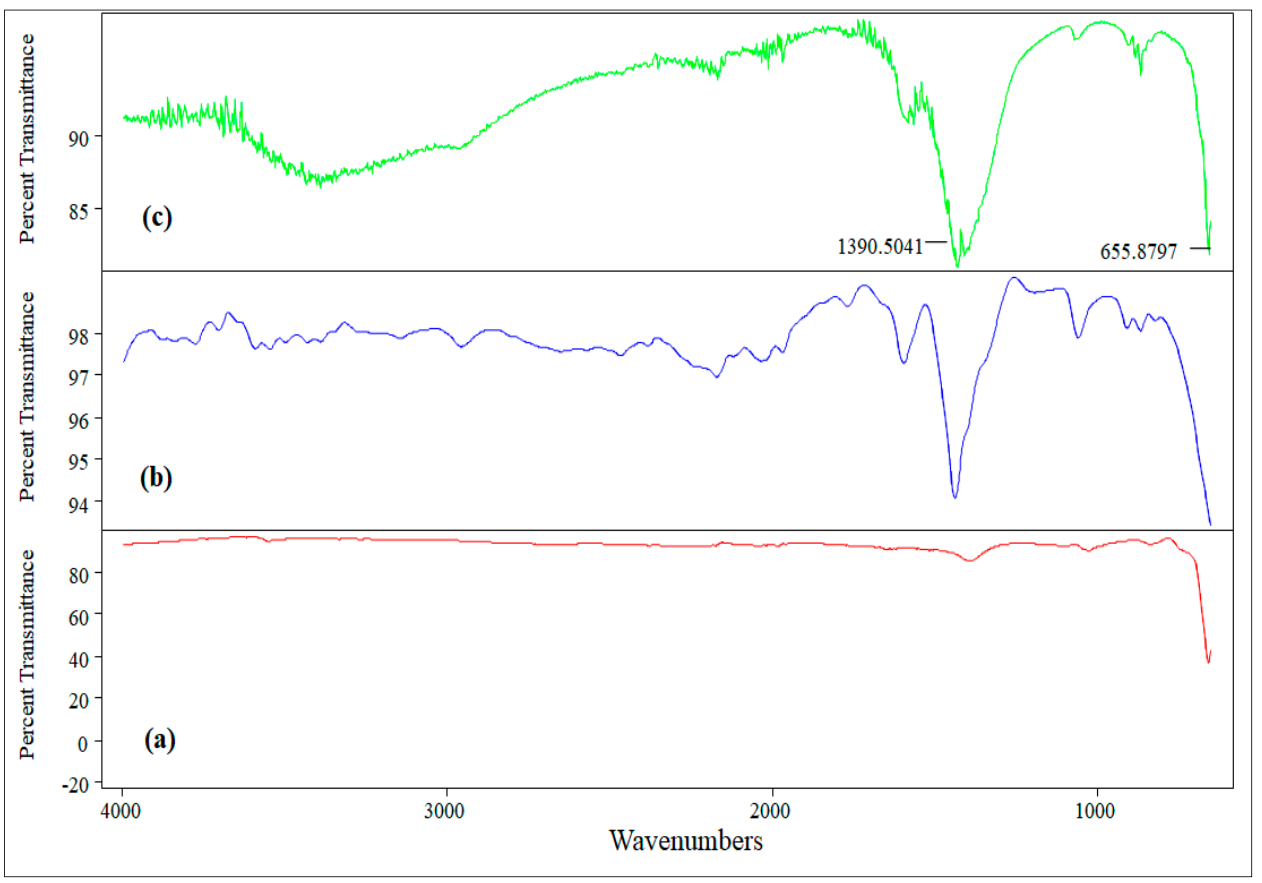

Figure 2. FTIR spectrum of (a) bismuth oxide $\mathrm{Bi}_{2} \mathrm{O}_{3}$ (NC1), (b) Bi0.8Ce0.2 nanocomposite oxide (NC2), (c) Bi0.5Ce0.5 nanocomposite oxide (NC3).

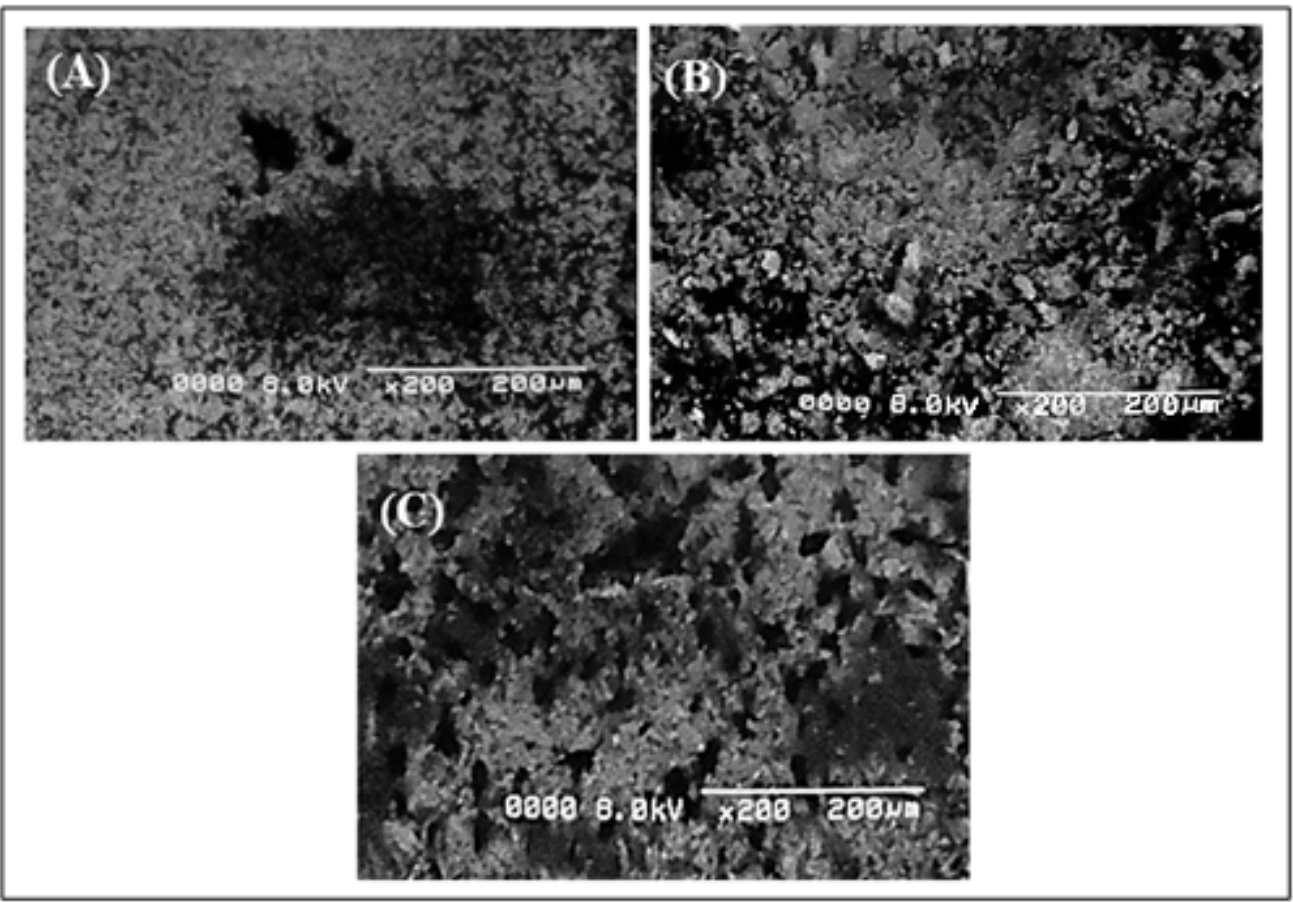

Figure 3. SEM images of (A) bismuth oxide $\mathrm{Bi}_{2} \mathrm{O}_{3}$ (NC1), (B) $\mathrm{Ce}_{0.2} \mathrm{Bi}_{0.8}$ nanocomposite oxide (NC2), (C) $\mathrm{Ce}_{0.5} \mathrm{Bi}_{0.5}$ nanocomposite oxide (NC3). 


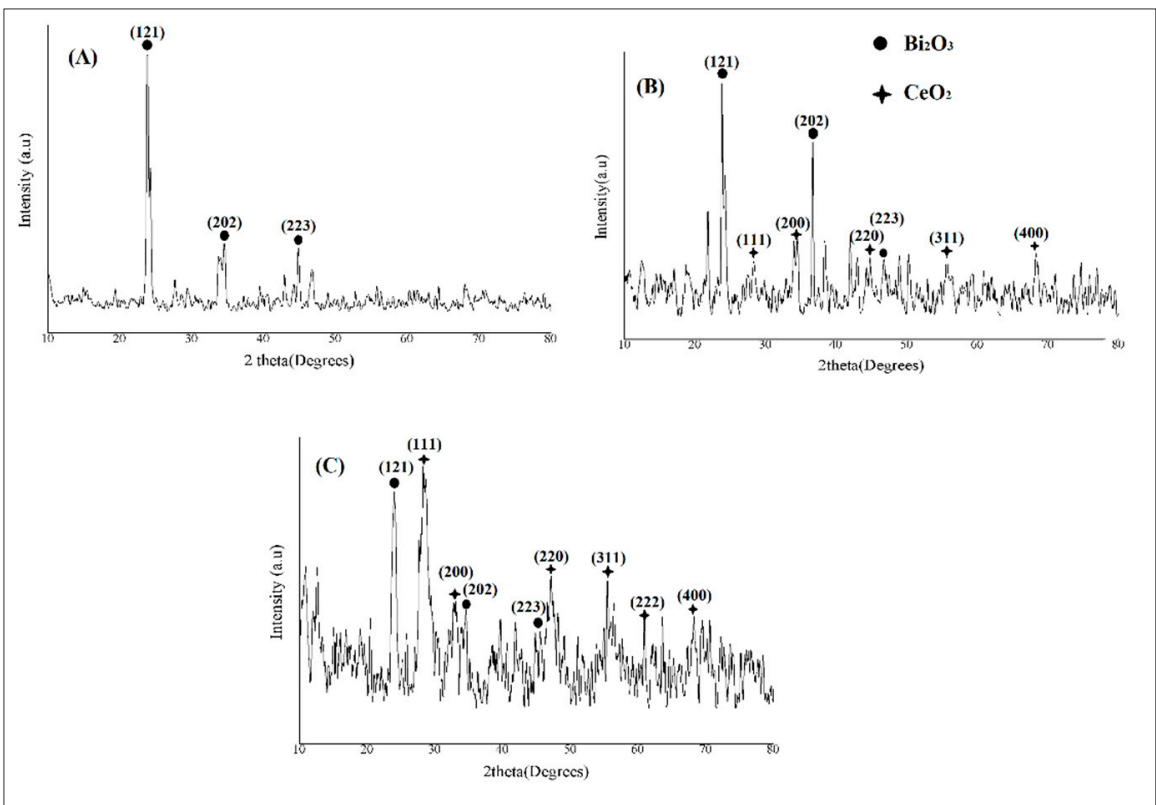

Figure 4. XRD pattern of (A) bismuth oxide $\mathrm{Bi}_{2} \mathrm{O}_{3}$ (NC1), (B) $\mathrm{Bi}_{0.8} \mathrm{Ce}_{0.2}$ nanocomposite oxide (NC2), (C) $\mathrm{Bi}_{0.5} \mathrm{Ce}_{0.5}$ nanocomposite oxide (NC3).

\subsection{Surface Modification of NBCs}

Evidence for the attachment of PDA to the surface of the metal oxide nanoparticles was obtained from the FTIR spectra of the bare and functionalized nanocomposites. The FTIR spectrum of bare NC1 (bismuth oxide nanoparticles) and NC1 coated with PDA is presented in Figure 5a. Four distinct peaks were observed in the spectrum of the surface modified NC2 nanoparticles. The absorption band at $3347 \mathrm{~cm}^{-1}$ was due to stretching vibrations of $\mathrm{O}-\mathrm{H}$ and $\mathrm{N}-\mathrm{H}$ groups in PDA. Furthermore, the sharp peaks at $1636 \mathrm{~cm}^{-1}$, $1494 \mathrm{~cm}^{-1}$, and $1278 \mathrm{~cm}^{-1}$ are attributed to the $\mathrm{C}=\mathrm{O}, \mathrm{C}=\mathrm{C}$, and $\mathrm{C}-\mathrm{O}$ bonds, respectively, present in PDA. The presence of these peaks in the FTIR spectra of our nanocomposites serves as verification for the PDA attachment to the nanoparticle surface. The findings obtained here confirm previously reported results [16].

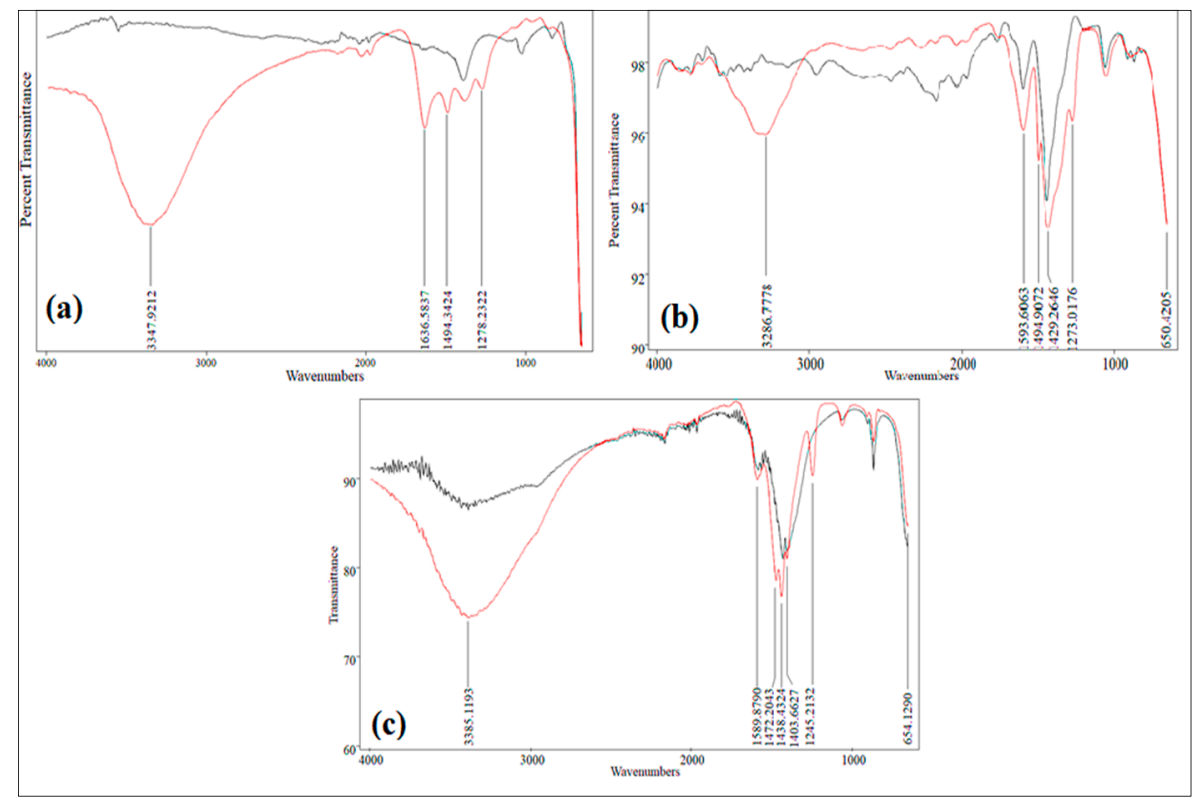

Figure 5. FTIR spectra of (a) NC1and PDA-coated NC1, (b) NC2 and PDA-coated NC2, (c) NC3 and PDA-coated NC3. 
Figure $5 \mathrm{~b}$ exhibits the IR spectrum of NC2 $\left(\mathrm{Ce}_{0.2} \mathrm{Bi}_{0.8}\right.$ nanocomposite oxide) and PDA-coated NC2. The nanoparticle surface modification with PDA is evident from the appearance of new prominent peaks. The absorption band at $3286 \mathrm{~cm}^{-1}$ represents the PDA stretching vibrations of the $\mathrm{O}-\mathrm{H}$ and $\mathrm{N}-\mathrm{H}$ groups. However, the noticeable peaks occurring at $1593 \mathrm{~cm}^{-1}, 1494 \mathrm{~cm}^{-1}$ and $1273 \mathrm{~cm}^{-1}$ correspond to $\mathrm{C}=\mathrm{O}, \mathrm{C}=\mathrm{C}$ and $\mathrm{C}-\mathrm{O}$ bond vibrations and clearly ascribe the presence of coating. The peak arising at $650 \mathrm{~cm}^{-1}$ proves the existence of nanoparticle metal oxide. Thus, the FTIR spectrum validates the grafting of the NC2 surface with PDA [12]. The FTIR spectrum of plain NC3 $\left(\mathrm{Ce}_{0.5} \mathrm{Bi}_{0.5}\right.$ nanocomposite oxide) and surface-modified (polydopamine covered) NC3 is shown in Figure $5 \mathrm{c}$. There are four observable absorption bands in the spectrum of the PDA-coated nanoparticles. The appearance of $\mathrm{O}-\mathrm{H}$ and $\mathrm{N}-\mathrm{H}$ group stretching vibrations at $3385 \mathrm{~cm}^{-1}$ signify the PDA attachment to the nanoparticle surface. In addition, the three sharp peaks at $1589 \mathrm{~cm}^{-1}, 1472 \mathrm{~cm}^{-1}$ and $1245 \mathrm{~cm}^{-1}$ evidence the presence of $\mathrm{C}=\mathrm{O}, \mathrm{C}=\mathrm{C}, \mathrm{C}-\mathrm{O}$ groups, respectively, that belong to PDA. Therefore, the FTIR spectra provide useful validating information for the PDA functionalization of the nanocomposites.

\subsection{Lipase Activities of NBCS}

The activities of the free $A$. niger lipase, lipase immobilized on PDA coated $\mathrm{Bi}_{2} \mathrm{O}_{3}$ (NBC1), lipase immobilized on PDA coated $\mathrm{Bi}_{0.8} \mathrm{Ce}_{0.2}$ composite oxide (NBC2), and lipase immobilized on PDA coated $\mathrm{Bi}_{0.5} \mathrm{Ce}_{0.5}$ composite oxide (NBC3) were 17.5, 15.3, 16.0 and $16.3 \mathrm{U} / \mathrm{mg}$, respectively. All three NBCs retained high lipase residual activity which can be attributed to the small size of the immobilization support. The highest residual lipase activity of $93 \%$ from the control (free lipase activity) was obtained with NBC3. The decrease in the enzyme activity of NBCs as compared to the free enzyme is apparently due to enzyme immobilization, a process in which some of the active sites of the free enzymes are blocked through binding to the surface of the immobilization support. Successful immobilization of lipase on nanomoieties is achieved through oxidative polymerization of dopamine on metal oxide surfaces which anchor the enzyme to the nanoparticles [17].

\subsection{Effect of $\mathrm{pH}$ and Temperature on Lipase Activity}

A maximum activity of $17.8 \mathrm{U} / \mathrm{mg}$ of the free lipase from $A$. niger was attained at $\mathrm{pH}$ 6 (Figure 6a). A sharp decline in the activity was observed at higher $\mathrm{pH}$. The optimum $\mathrm{pH}$ for the immobilized lipases from NBC1 and NBC2 was $\mathrm{pH} 6$ whereas, NBC3 had a $\mathrm{pH}$ optimum of 7, with a maximum activity of $16.2 \mathrm{U} / \mathrm{mg}$. Noteworthy, the activity of the NBC3 lipase was around the maximum and formed a plateau in the $\mathrm{pH}$ range 5-8, as can be seen from Figure 6. Overall, the immobilized NBC lipase showed a greater stability in the alkaline $\mathrm{pH}$ range compared to the free enzyme. For example, at $\mathrm{pH}$ 10, $\mathrm{NBC} 3\left(\mathrm{CeO}_{2} \cdot \mathrm{Bi}_{2} \mathrm{O}_{3}\right.$ @ $\mathrm{PDA} @$ A.niger.Lipase) retained $12.5 \mathrm{U} / \mathrm{mg}$ lipase activity $(77 \%$ of maximum activity) whereas the free enzyme had only $7.8 \mathrm{U} / \mathrm{mg}$ of activity ( $44 \%$ of maximum activity). The improved stability of the immobilized enzyme can be explained with the shielding effect that functionalized nanoparticles exert toward $\mathrm{pH}$ changes in the immediate surroundings of the NBC.

The effect of temperature on the performance of the free and immobilized A. niger lipases was studied in the temperature range $25-50{ }^{\circ} \mathrm{C}$ (Figure 6b). The optimum activity of the free lipase was $30^{\circ} \mathrm{C}$. The immobilized NBC lipases displayed higher optimum temperature of $35^{\circ} \mathrm{C}$ (NBC2) and $40^{\circ} \mathrm{C}(\mathrm{NBC} 1$ and NBC3). As observed with $\mathrm{pH}$ (Figure 6a), the immobilized enzymes possessed higher stability towards temperature variations as compared to the free enzyme. The maximum lipase activities for NBC1 and NBC3 were $15.4 \mathrm{U} / \mathrm{mg}$ and $16.5 \mathrm{U} / \mathrm{mg}$, respectively. At $50{ }^{\circ} \mathrm{C}, \mathrm{NBC} 3$ retained $76 \%$ of its maximal activity. Immobilized enzymes are known to withstand harsh environmental conditions which proves beneficial in applications such as biodiesel production where low reaction temperatures can increase feedstock's viscosity thereby resulting in decreased reaction rates [18]. Hence, the use of immobilized lipase with improved temperature stability would maintain a higher biodiesel production rate. 


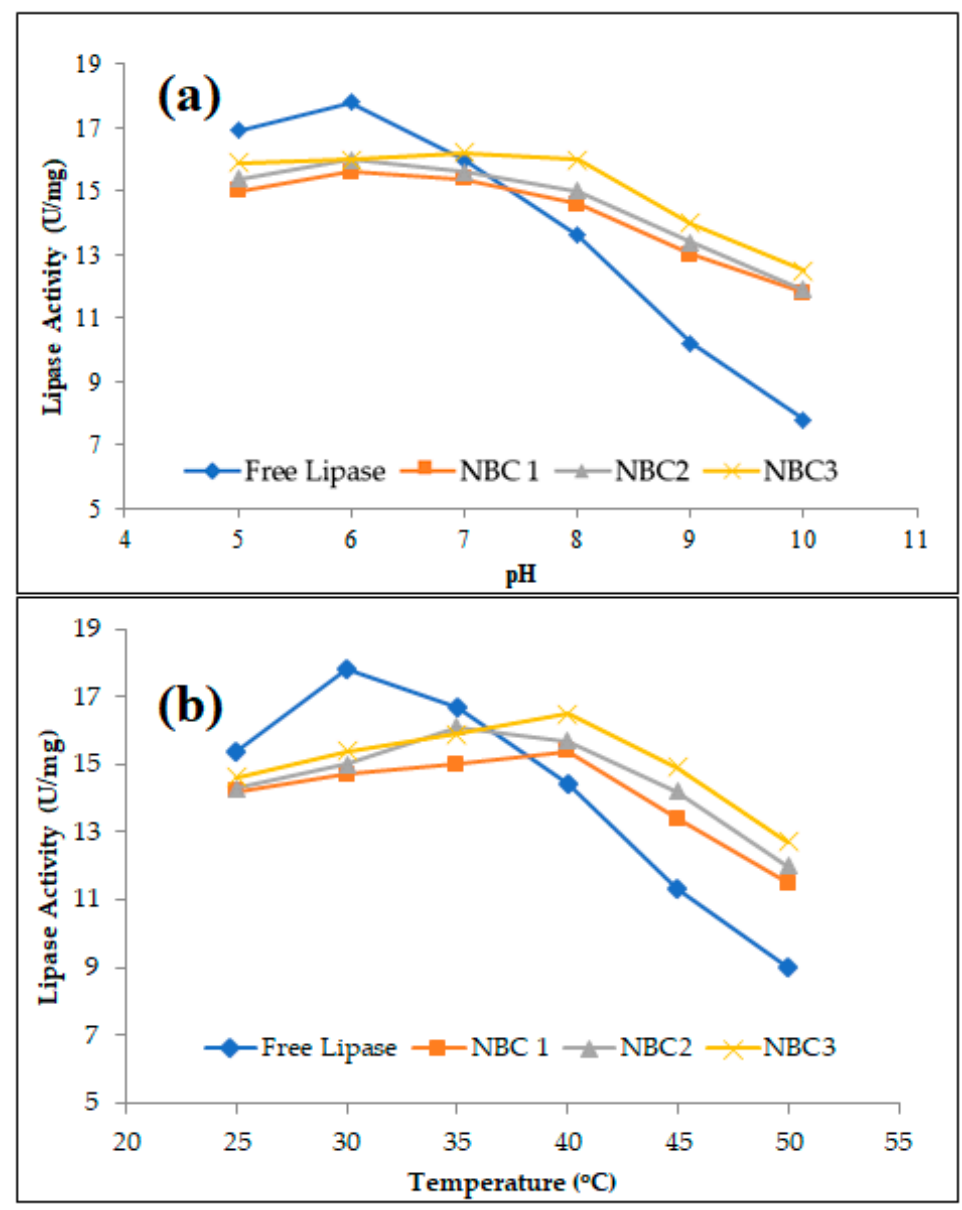

Figure 6. Impact of (a) $\mathrm{pH}(\mathbf{b})$ temperature on enzyme activity of free and immobilized A. niger lipase.

\subsection{Reusability of NBCs}

The NBC lipases were examined for their reusability potential in transesterification of E. sativa oil to biodiesel at their respective $\mathrm{pH}$ and temperature optima (Figure 7). The NBCs were recycled eight times, their residual activities were measured after each cycle, and results were compared. Best results were obtained with NBC3 which retained $59 \%$ of its initial activity after eight repeated uses. This might be due to the higher concentrations of cerium in the nanobiocomposite that is known to have a high oxidative potential to bind and hold compounds like PDA and lipase to the surface [9]. The high content of cerium oxide in the NCs leads to entrapment of oxygen in the NC crystals as well as adsorption of oxygen on the NC surface. This results in better oxidative properties [7]. The polymerization of dopamine is facilitated on oxidative surfaces, such as NC3 [9].

Overall, NBC3 had higher maximum and residual activity and better temperature and $\mathrm{pH}$ stability than the other nanobiocatalysts ( $\mathrm{NBC} 1$ and $\mathrm{NBC} 2$ ). It appeared as the most compelling nanobiocatalyst in this study, and for the reasons above, it was chosen for further optimization studies on biodiesel production.

\subsection{Optimization of Biodiesel Production with NBC3 as Biocatalyst}

The experimental results showed that a maximum biodiesel yield of $90.6 \%$ using $\mathrm{NBC} 3$ as biocatalyst was achieved under the following conditions: reaction time, $60 \mathrm{~h}$; $\mathrm{NBC} 3$ concentration, $5 \%(w / w)$; methanol: oil ratio of $6: 1$. The results from all 30 runs were analyzed to select the most suitable statistical model for the optimization studies. Table 1 compiles the statistical data for the different models. The quadratic model was selected as the statistical model of choice due to the model significance, high predicted and adjusted squared values as well as insignificant lack of fit test $(p>0.05)$ [19]. 


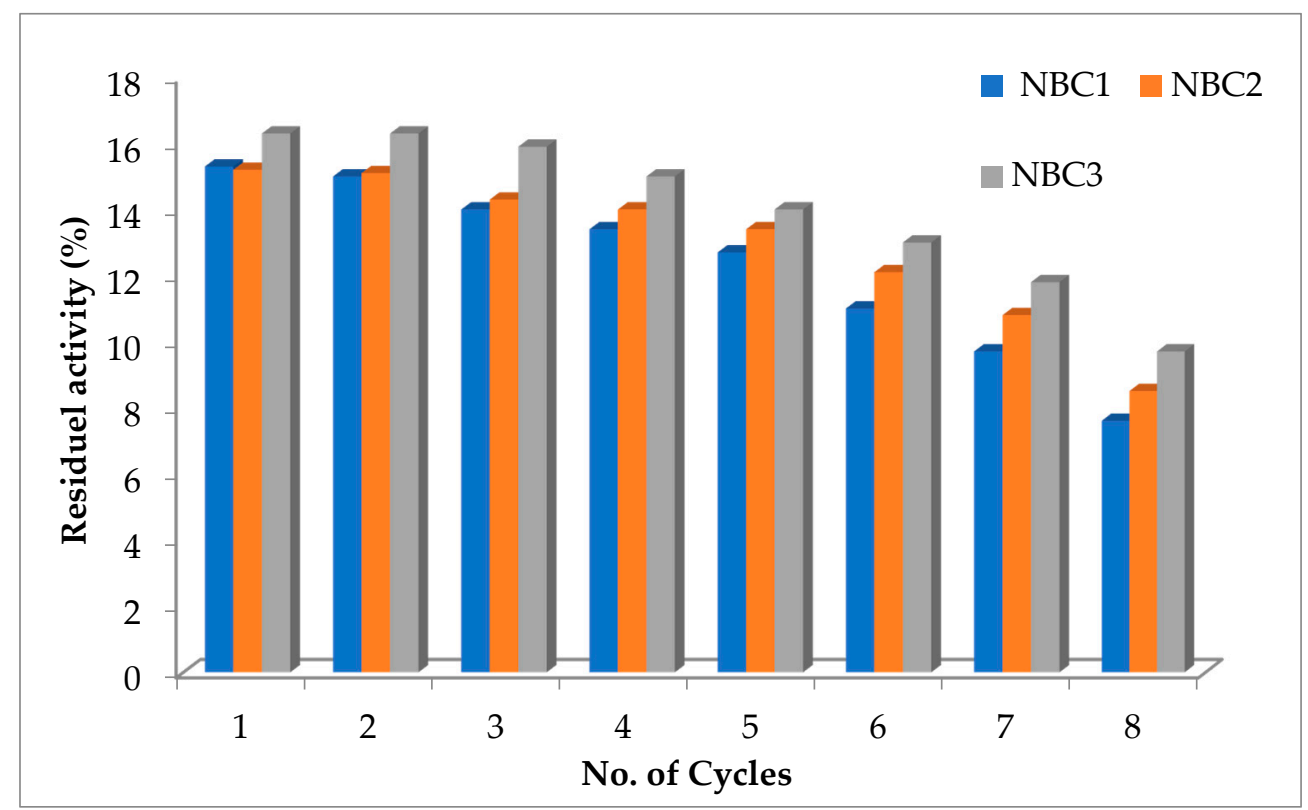

Figure 7. Reusability of NBC lipases.

Table 1. Summary of model fitness.

\begin{tabular}{cccccc}
\hline Source & $\begin{array}{c}\text { Sequential } \\
\boldsymbol{p} \text {-Value }\end{array}$ & $\begin{array}{c}\text { Lack of Fit } \\
\boldsymbol{p} \text {-Value }\end{array}$ & $\begin{array}{c}\text { Adjusted } \\
\text { R-Squared }\end{array}$ & $\begin{array}{c}\text { Predicted } \\
\text { R-Squared }\end{array}$ & \\
\hline Linear & 0.0027 & 0.0016 & 0.4984 & 0.2398 & \\
2FI & 0.8241 & 0.0009 & 0.4228 & -1.5370 & Suggested \\
Quadratic & $<0.0001$ & 0.7517 & 0.9753 & 0.9537 & \\
Cubic & 0.7517 & & 0.9676 & & \\
\hline
\end{tabular}

The validity of the quadratic model was also verified from the normality plot of residuals and predicted vs. actual plot (Figure 8). The normal data distribution points in normality plot without any strong outliers is indicative of the suitability of the quadratic model. Moreover, the similar predicted and actual values also supports the validity of the quadratic model for biodiesel yield data [3].

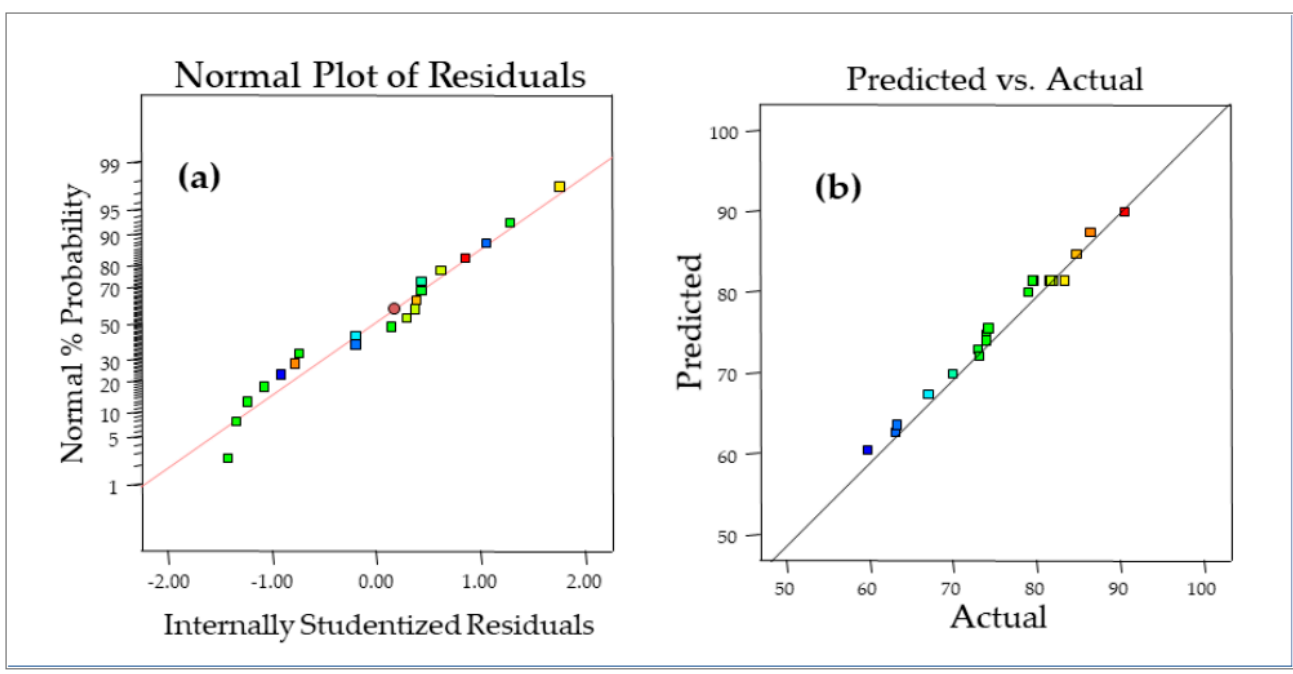

Figure 8. Normality plot of (a) residual, (b) predicted vs. residual. 
The analysis of variance (ANOVA) for the quadratic model is provided in Table 2. The table presents the significance level of different linear, quadratic and first order interaction terms. The terms with $p$-value $<0.05$ have significant effect on the response (biodiesel yield). The ANOVA table indicates that biodiesel yield was being significantly affected by all selected linear terms, i.e., reaction time, NBC3 concentration, and methanol: oil. While AB (reaction time $x$ NBC Concentration was the only first order interaction term with significant effect on biodiesel yield. Among quadratic terms, the (Reaction Time) ${ }^{2}$ and (methanol: oil) ${ }^{2}$ were the significant terms [20].

Table 2. ANOVA for the quadratic model for percentage biodiesel yield.

\begin{tabular}{cccccc}
\hline Source & $\begin{array}{c}\text { Sum of } \\
\text { Squares }\end{array}$ & Df & $\begin{array}{c}\text { Mean } \\
\text { Square }\end{array}$ & F Value & $\begin{array}{c}\boldsymbol{p} \text {-Value } \\
\text { Prob }>\text { F }\end{array}$ \\
\hline Model & 1305.53 & 9 & 145.06 & 84.32 & $<0.0001$ \\
A-Reaction & 130.04 & 1 & 130.04 & 75.59 & $<0.0001$ \\
Time & 471.13 & 1 & 471.13 & 273.86 & $<0.0001$ \\
B-NBC Conc. & 28.90 & 1 & 28.90 & 16.80 & 0.0021 \\
C-Methanol: & 26.64 & 1 & 26.64 & 15.49 & 0.0028 \\
oil & 1.36 & 1 & 1.36 & 0.79 & 0.3946 \\
AB & 0.36 & 1 & 0.36 & 0.21 & 0.6566 \\
AC & 17.46 & 1 & 17.46 & 10.15 & 0.0097 \\
BC & 1.10 & 1 & 1.10 & 0.64 & 0.4422 \\
A $^{2}$ & 173.50 & 1 & 173.50 & 100.85 & $<0.0001$ \\
B $^{2}$ & 17.20 & 10 & 1.72 & & 0.7517 \\
C $^{2}$ & 5.92 & 5 & 1.18 & 2.26 & 0.53 \\
Residual & 11.28 & 19 & & & 0
\end{tabular}

The quadratic equation to calculate the biodiesel yield containing different variables is given below:

Biodiesel Yield $=+81.23+3.71 \times \mathrm{A}+6.68 \times \mathrm{B}-1.70 \times \mathrm{C}+1.76 \times \mathrm{AB}-0.41 \times \mathrm{AC}-0.21 \times \mathrm{BC}-2.92 \times \mathrm{A}^{2}-0.68 \times \mathrm{B}^{2}-7.59 \times \mathrm{C}^{2}$

The three-dimensional presentation of the effect of first order interaction terms on biodiesel yield is demonstrated by the response surface plots (Figure 9). The combined effect of NBC3 concentration and reaction time, as presented in Figure 9a, indicates that both factors have a positive effect on the biodiesel yield, and increasing the NBC3 concentration and reaction time leads to increased biodiesel yield. An increased amount of NBC3 provides more active sites for the catalytic process while longer reaction times allow completion of the transesterification reaction. The effect of reaction time (A) and methanol: oil ratio (C) on the response surface plots is presented in Figure 9b. Biodiesel yield can be seen increasing with the reaction time; however, methanol/oil ratios above 6 decreased the biodiesel yield. This suggests that excess amounts of methanol, a short-chain alcohol, inhibit the lipase activity and inactivates the NBC3 biocatalyst. Figure 9c presents the mutual effect of methanol: oil and NBC concentration on biodiesel yield. Similar studies were also performed by our group [8]. Different lipases were immobilized on PDAcoated $\mathrm{Fe}_{3} \mathrm{O}_{4}$ nanoparticles, $\mathrm{CeO}_{2}$ nanoparticles and titanium oxide nanoparticles. The NBCs were used for transesterification of waste cooking oil, E. sativa oil, and Jatropha oil, respectively. The NBCs produced optimum biodiesel yield at different reaction conditions dependent on the nanosupport and type of enzyme utilized. In the current study, which is a continuation from our previous work, we have used a cerium oxide-bismuth oxide-based nanocomposite as nanosupport for $A$. niger lipase to attain a $92 \%$ biodiesel yield from $E$. sativa oil as compared to $89.3 \%$ yield obtained by transesterification of the same oil with $\mathrm{CeO}_{2} @ P D A @ A$-terreus [8]. 


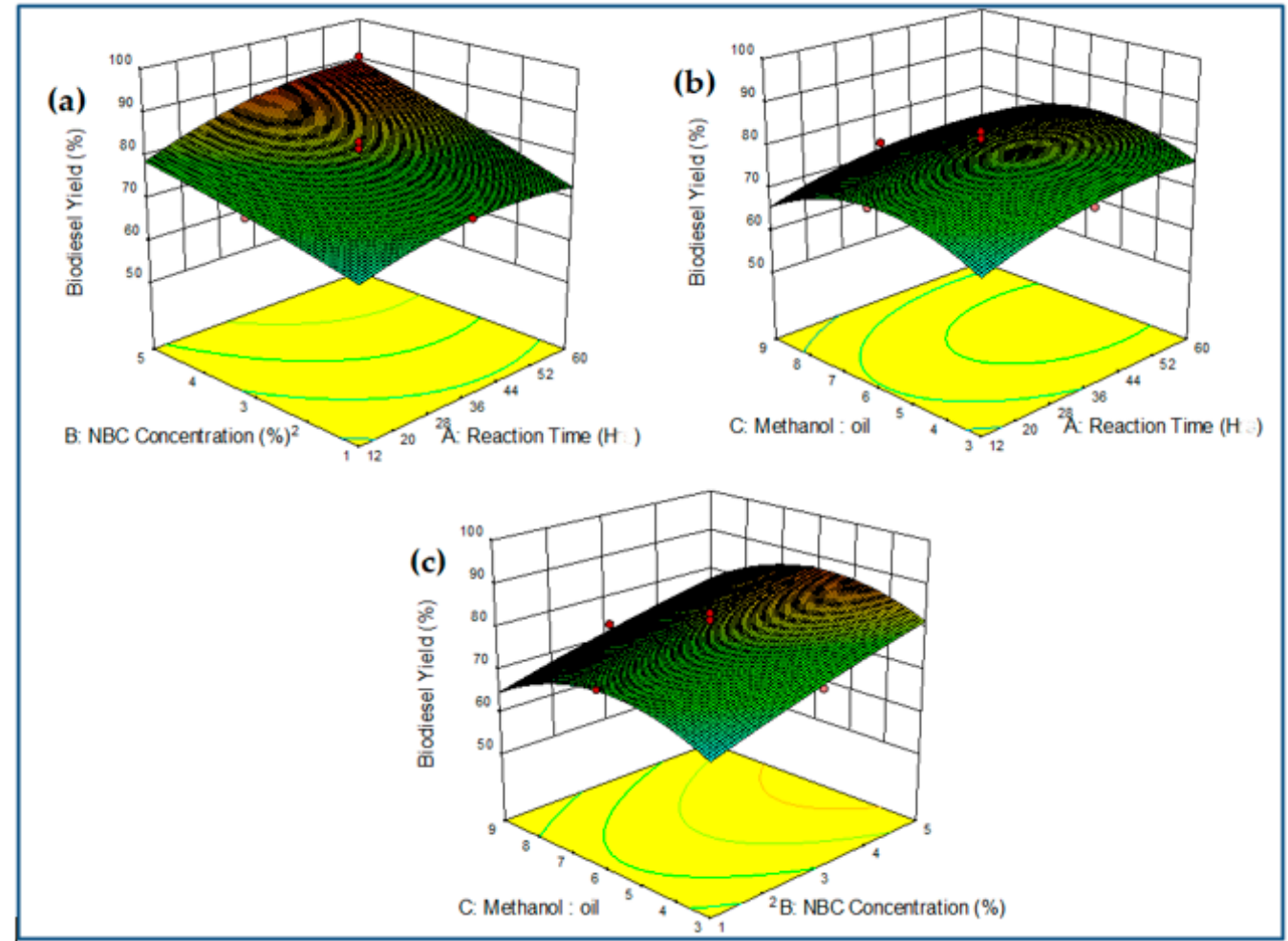

Figure 9. Response surface plots for significant interaction terms: (a) mutual effects of NBC3 concentration and reaction time on biodiesel yield, (b) mutual effects of reaction time and the methanol: oil ratio on biodiesel yield, (c) mutual effects of methanol: oil ratio and of NBC concentration on biodiesel yield.

\subsection{Characterization of Biodiesel}

The biodiesel produced with the NBC3 biocatalyst was subjected to FTIR analysis to ascertain the formation of FAME. For the FTIR spectroscopic monitoring of biodiesel synthesis, the FTIR spectra of both the reactant (E. sativa oil) and the product (biodiesel) were analyzed in the $400-4000 \mathrm{~cm}^{-1}$ range (Figure 10). The appearance of new peaks at $1436 \mathrm{~cm}^{-1}$ and $1197 \mathrm{~cm}^{-1}$ in the FTIR of biodiesel (Figure 10b) confirms the formation of FAME. These peaks are indicative of the presence of FAME $\left(1436 \mathrm{~cm}^{-1}\right)$ and reflect the vibrations of the C-O bond $\left(1197 \mathrm{~cm}^{-1}\right)$ in FAME [20].

The compositional analysis of biodiesel from E. sativa oil was carried by GC-MS. The major FAME identified in biodiesel were hexadecanoic acid methyl ester, 9-octadecenoic acid methyl ester, 11-eicosenoic acid methyl ester, 3-docosenoic acid methyl easter, erucic acid methyl ester, and 15-tetracosenoic acid methyl ester (Table 3). The major component of FAME was the methyl ester of erucic acid (a docosenoic acid having a cis-double bond at C13), with $47.7 \%$ of the total FAME content. The results obtained in the present study are in alliance with previous studies $[8,21]$. 


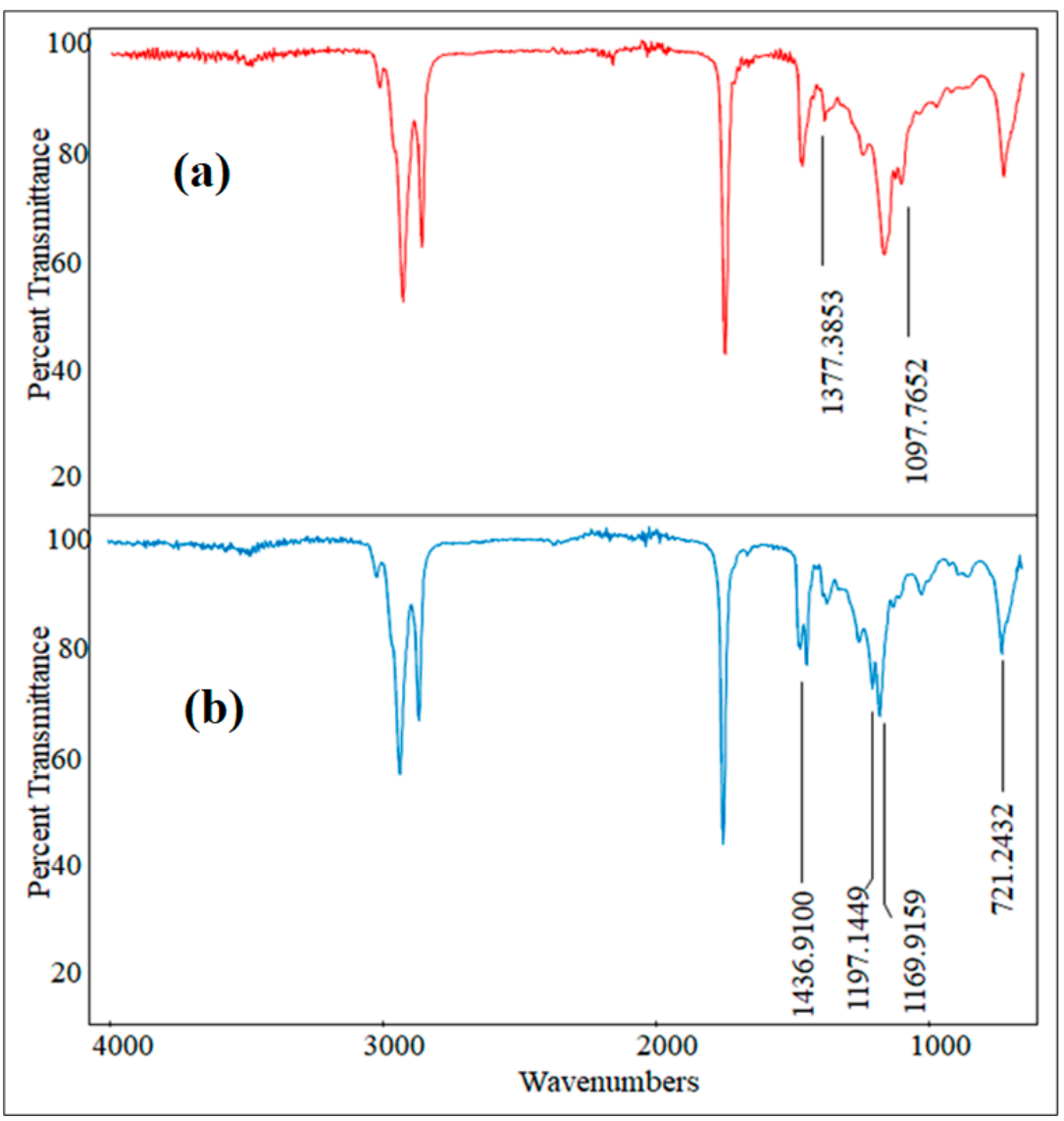

Figure 10. FTIR spectra of (a) E. sativa oil, (b) biodiesel from E. sativa oil.

Table 3. FAME composition of biodiesel from E. sativa oil.

\begin{tabular}{cccc}
\hline $\begin{array}{c}\text { Peak } \\
\#\end{array}$ & $\begin{array}{c}\text { Retention Time } \\
(\mathbf{m i n})\end{array}$ & FAME & $\begin{array}{c}\% \\
(\boldsymbol{w} / \boldsymbol{w})\end{array}$ \\
\hline 1 & 16.868 & $\begin{array}{c}\text { Hexadecanoic acid } \\
\text { methy ester } \\
\text { 9-Octadecenoic acid } \\
\text { methyl ester }\end{array}$ & 1.9 \\
3 & 18.681 & $\begin{array}{c}\text { 11-Eicosenoic acid } \\
\text { methy ester }\end{array}$ & 42.6 \\
4 & 20.358 & $\begin{array}{c}\text { Erucic acid methyl } \\
\text { ester }\end{array}$ & 47.5 \\
5 & 22.129 & $\begin{array}{c}\text { 15-Tetracosenoic acid } \\
\text { methyl ester }\end{array}$ & 0.3 \\
\hline
\end{tabular}

\section{Conclusions}

In the present study, a novel nanobiocatalyst with high lipase activity was synthesized and evaluated in transesterification of E. sativa vegetable oil to biodiesel. The nanobiocatalyst was produced in three steps: (1) synthesis of COBO nanoparticles; (2) PDA coating of the $\mathrm{COBO}$ nanoparticle surface; and (3) immobilization of $A$. niger lipase on the $\mathrm{CeO}_{2} \cdot \mathrm{Bi}_{2} \mathrm{O}_{3} @ \mathrm{PDA}$ nanocomposite support. Based on maximum lipase activity $(16.2 \mathrm{U} / \mathrm{mg})$, $\mathrm{pH}$ stability $(77 \%$ residual activity at $\mathrm{pH} 10)$, temperature stability $(76 \%$ residual activity at $\left.50{ }^{\circ} \mathrm{C}\right)$, and reusability ( $59 \%$ residual activity after 8 recycles), NBC3 was identified as the best $\mathrm{COBO}$-based $\left(\mathrm{CeO}_{2} \cdot \mathrm{Bi}_{2} \mathrm{O}_{3}\right.$. $\mathrm{PDA} @$ A.niger.Lipase) biocatalyst for further optimization studies on biodiesel production. The transesterification reaction was statistically optimized using RSM. A maximum biodiesel yield of $90.6 \%$ was obtained at methanol to oil ratio of $6: 1, \mathrm{NBC} 3$ concentration of $5 \%(w / v)$, and reaction time of $60 \mathrm{~h}$. The broad $\mathrm{pH}$ optimum, 
robustness towards $\mathrm{pH}$ and temperature variations, and opportunities for catalyst recycling expand the potential applicability of NBC3 as a biocatalyst. The newly synthesized NBC lipase has the potential to (1) produce high biodiesel yields, and (2) improve the biodiesel production economics due to reusability of the solid biocatalyst. Further work is underway to evaluate the biocatalyst in transesterification of other vegetable oils for improved biodiesel yield.

Author Contributions: Conceptualization, A.S., H.M. and M.W.M.; methodology, A.S., H.M., S.A. and M.W.M.; formal analysis, H.M. and T.T.; writing-original draft preparation, A.S., S.A., T.T. and M.W.M.; software and validation, H.M. and T.T.; final review, editing and final draft preparation, H.M., V.Z. and L.C. All authors have read and agreed to the published version of the manuscript.

Funding: This research received no external funding.

Conflicts of Interest: The authors declare no conflict of interest.

\section{References}

1. Mumtaz, M.W.; Adnan, A.; Anwar, F.; Mukhtar, H.; Raza, M.A.; Ahmad, F.; Rashid, U. Response surface methodology: An emphatic tool for optimized biodiesel production using rice bran and sunflower oils. Energies 2012, 5, 3307-3328. [CrossRef]

2. Talebian-Kiakalaieh, A.; Amin, N.A.S.; Mazaheri, H. A review on novel processes of biodiesel production from waste cooking oil. Appl. Energy 2013, 104, 683-710. [CrossRef]

3. Sohail, S.; Mumtaz, M.W.; Mukhtar, H.; Touqeer, T.; Anjum, M.K.; Rashid, U.; Wan Ab Karim Ghani, W.A.; Choong, T.S.Y. Spirogyra Oil-Based Biodiesel: Response Surface Optimization of Chemical and Enzymatic Transesterification and Exhaust Emission Behavior. Catalysts 2020, 10, 1214. [CrossRef]

4. Akoh, C.C.; Chang, S.-W.; Lee, G.-C.; Shaw, J.-F. Enzymatic approach to biodiesel production. J. Agric. Food Chem. 2007, 55, 8995-9005. [CrossRef]

5. Touqeer, T.; Mumtaz, M.W.; Mukhtar, H.; Irfan, A.; Akram, S.; Shabbir, A.; Rashid, U.; Nehdi, I.A.; Choong, T.S.Y. Fe ${ }_{3} \mathrm{O}_{4}-$ PDA-Lipase as Surface Functionalized Nano Biocatalyst for the Production of Biodiesel Using Waste Cooking Oil as Feedstock: Characterization and Process Optimization. Energies 2020, 13, 177. [CrossRef]

6. Bi, Y.; Wang, Z.; Zhang, R.; Diao, Y.; Tian, Y.; Jin, Z. Improved catalytic properties of Thermomyces lanuginosus lipase immobilized onto newly fabricated polydopamine-functionalized magnetic $\mathrm{Fe}_{3} \mathrm{O}_{4}$ nanoparticles. Processes 2020, 8, 629. [CrossRef]

7. Akram, S.; Wang, Z.; Chen, L.; Wang, Q.; Shen, G.; Han, N.; Chen, Y.; Ge, G. Low-temperature efficient degradation of ethyl acetate catalyzed by lattice-doped $\mathrm{CeO}_{2}-\mathrm{CoO}_{x}$ nanocomposites. Catal. Commun. 2016, 73, 123-127. [CrossRef]

8. Fatima, A.; Mumtaz, M.W.; Mukhtar, H.; Akram, S.; Touqeer, T.; Rashid, U.; Ul Mustafa, M.R.; Nehdi, I.A.; Saiman, M.I. Synthesis of lipase-immobilized $\mathrm{CeO}_{2}$ nanorods as heterogeneous nano-biocatalyst for optimized biodiesel production from Eruca sativa seed oil. Catalysts 2020, 10, 231. [CrossRef]

9. Zulfiqar, A.; Mumtaz, M.W.; Mukhtar, H.; Najeeb, J.; Irfan, A.; Akram, S.; Touqeer, T.; Nabi, G. Lipase-PDA-TiO 2 NPs: An emphatic nano-biocatalyst for optimized biodiesel production from Jatropha curcas oil. Renew. Energy 2021, 169, $1026-1037$. [CrossRef]

10. Li, F.; Hülsey, M.J.; Yan, N.; Dai, Y.; Wang, C.-H. Co-transesterification of waste cooking oil, algal oil and dimethyl carbonate over sustainable nanoparticle catalysts. Chem. Eng. J. 2021, 405, 127036. [CrossRef] [PubMed]

11. Zhao, Y.; Wang, C.; Zhang, L.; Chang, Y.; Hao, Y. Converting waste cooking oil to biodiesel in China: Environmental impacts and economic feasibility. Renew. Sustain. Energy Rev. 2021, 140, 110661. [CrossRef]

12. Jayakumar, G.; Irudayaraj, A.A.; Raj, A.D. Investigation on the synthesis and photocatalytic activity of activated carbon-cerium oxide (AC-CeO ${ }_{2}$ ) nanocomposite. Appl. Phys. A 2019, 125, 1-9. [CrossRef]

13. Pujar, M.S.; Hunagund, S.M.; Desai, V.R.; Patil, S.; Sidarai, A.H. One-step synthesis and characterizations of cerium oxide nanoparticles in an ambient temperature via Co-precipitation method. AIP Conf. Proc. 2018, 1942, 050026.

14. Wang, H.-W.; Hu, Z.-A.; Chang, Y.-Q.; Chen, Y.-L.; Lei, Z.-Q.; Zhang, Z.-Y.; Yang, Y.-Y. Facile solvothermal synthesis of a graphene nanosheet-bismuth oxide composite and its electrochemical characteristics. Electrochim. Acta 2010, 55, 8974-8980. [CrossRef]

15. He, C.; Yu, Y.; Yue, L.; Qiao, N.; Li, J.; Shen, Q.; Yu, W.; Chen, J.; Hao, Z. Low-temperature removal of toluene and propanal over highly active mesoporous $\mathrm{CuCeOx}$ catalysts synthesized via a simple self-precipitation protocol. Appl. Catal. B Environ. 2014, 147, 156-166. [CrossRef]

16. Sun, Y.; Wang, C.; Tang, L.; Zhang, Y.; Zhang, G.-J. Magnetic-enhanced fluorescence sensing of tumor miRNA by combination of MNPs@ PDA with duplex specific nuclease. RSC Adv. 2021, 11, 2968-2975. [CrossRef]

17. Moyo, L.; Iyuke, S.; Muvhiiwa, R.; Simate, G.; Hlabangana, N. Application of response surface methodology for optimization of biodiesel production parameters from waste cooking oil using a membrane reactor. S. Afr. J. Chem. Eng. 2021, 35, 1-7. [CrossRef]

18. Helmi, M.; Tahvildari, K.; Hemmati, A.; Safekordi, A. Phosphomolybdic acid/graphene oxide as novel green catalyst using for biodiesel production from waste cooking oil via electrolysis method: Optimization using with response surface methodology (RSM). Fuel 2021, 287, 119528. [CrossRef] 
19. Mukhtar, H.; Khursheed, S.; Mumtaz, M.W.; Rashid, U.; Al-Resayes, S.I. Optimization of lipase biosynthesis from Rhizopus oryzae for biodiesel production using multiple oils. Chem. Eng. Technol. 2016, 39, 1707-1715. [CrossRef]

20. Mukhtar, H.; Suliman, S.M.; Shabbir, A.; Mumtaz, M.W.; Rashid, U.; Rahimuddin, S.A. Evaluating the Potential of Oleaginous Yeasts as Feedstock for Biodiesel Production. Protein Pept. Lett. 2018, 25, 195-201. [CrossRef]

21. Mumtaz, M.W.; Adnan, A.; Mahmood, Z.; Mukhtar, H.; Danish, M.; Ahmad, Z. Biodiesel production using Eruca sativa oil: Optimization and characterization. Pak. J. Bot. 2012, 44, 1111-1120. 